\title{
Glottic Cancer pN2c TNM Finding v6 and v7
}

National Cancer Institute

\section{Source}

National Cancer Institute. Glottic Cancer pN2c TNM Finding v6 and v7. NCI Thesaurus.

Code C64690.

Glottic cancer with metastasis in bilateral or contralateral lymph nodes, none more than 6 $\mathrm{cm}$ in greatest dimension. (from AJCC 6th and 7th Eds.) 